CLINICAL STUDY

\title{
Homozygous and heterozygous expression of a novel mutation of the acid-labile subunit
}

\author{
H A van Duyvenvoorde ${ }^{1,2,3}$, M J E Kempers ${ }^{4}$, Th B Twickler ${ }^{4}$, J van Doorn ${ }^{5}$, W J Gerver ${ }^{6}$, C Noordam ${ }^{7}$, \\ M Losekoot $^{3}$, M Karperien ${ }^{2,8}$, J M Wit ${ }^{1}$ and A R M M Hermus ${ }^{4}$ \\ ${ }^{1}$ Departments of Paediatrics, ${ }^{2}$ Endocrinology and Metabolic Diseases and ${ }^{3}$ Center for Human and Clinical Genetics, Leiden University Medical Center, 2300 \\ RC Leiden, The Netherlands, ${ }^{4}$ Department of Endocrinology, University Medical Center Nijmegen, Radboud University, Nijmegen, The Netherlands, \\ ${ }^{5}$ Department of Metabolic and Endocrine Diseases, University Medical Center Utrecht, Utrecht, The Netherlands, ${ }^{6}$ Department of Paediatrics, University \\ Medical Center Maastricht, Maastricht, The Netherlands, ${ }^{7}$ Department of Paediatrics, University Medical Center Nijmegen, Radboud University, Nijmegen, \\ The Netherlands and ${ }^{8}$ Department of Tissue Regeneration, University of Twente, Enschede, The Netherlands
}

(Correspondence should be addressed to H A van Duyvenvoorde who is now at Department of Human and Clinical Genetics, C4-R, Leiden University Medical Center, PO Box 9600,2300 RC Leiden, The Netherlands; Email: h.a.van_duyvenvoorde@lumc.nl)

Th B Twickler is now at Department of Vascular Medicine, Academic Medical Center, Amsterdam, The Netherlands

\begin{abstract}
Context: Acid-labile subunit (ALS) deficiency due to homozygous inactivation of the ALS gene (IGFALS) is associated with moderate short stature, and in few cases pubertal delay. The clinical expression of heterozygosity is unknown.

Objective: To investigate the clinical, laboratory, and radiological features of homozygous and heterozygous carriers of a novel mutation in the $A L S$ gene in comparison with non-carriers.

Subjects: Three short Kurdish brothers and their relatives.

Results: The index cases presented with short stature, microcephaly, and low circulating IGF-I and IGFbinding protein-3 (IGFBP-3), and undetectable ALS levels. Two were known with a low bone mineral density and one of them had suffered from two fractures. We found a novel homozygous ALS gene mutation resulting in a premature stop codon (c.1490dupT, p.Leu497PhefsX40). The IGF-I, IGFBP-3, and ALS $150 \mathrm{kDa}$ ternary complex was absent, and ALS proteins in serum were not detected with western blot. IGFPB-1 and IGFPB-2 were low and there was a mild insulin resistance. Five heterozygous carriers tended to have a lower height and head circumference than five non-carriers, and had low plasma ALS and IGFBP-3 levels. Bone mineral (apparent) density was low in two out of three homozygous carriers, and also in four out of nine relatives.

Conclusions: The clinical presentation of homozygous ALS mutations may, besides short stature, include microcephaly. Heterozygous carriers may have less statural and head growth, suggestive for a gene dosage effect.
\end{abstract}

European Journal of Endocrinology 159 113-120

\section{Introduction}

For both humans and rodents, it has been well established that insulin-like growth factor-I (IGF-I) plays a critical role in the regulation of intrauterine growth and development and postnatal growth and metabolism $(1,2)$. Total IGF-I deficiency leads to severe intrauterine and postnatal growth failure, microcephaly, mental retardation, and deafness $(3,4)$. Partial IGF-I resistance due to heterozygous mutations in the IGF-I receptor (IGF1R) gene results in moderate intrauterine and postnatal growth retardation and microcephaly (5-8).

A third defect that is associated with a reduced bioavailability of IGF-I is caused by a mutation in the acid-labile subunit gene (ALS). ALS can form, together with IGF-I (or IGF-II) and IGF-binding protein-3 (IGFBP-3, or IGFBP-5 for only $10 \%$ ), a $150 \mathrm{kDa}$ ternary complex.
Under normal circumstances, $80-85 \%$ of circulating IGF-I is retained in this complex (9). The $150 \mathrm{kDa}$ complexes cannot cross the capillary endothelial barrier, which prolongs the half-life of IGFs, IGFBP-3 and IGFBP-5, in the circulation (9-11). This seems to play an important role in the regulation of the bioavailability of IGFs to the tissue compartments.

ALS belongs to the superfamily of leucine-rich repeat (LRR) proteins, characterized by their ability to participate in protein-protein interactions. About 75\% of the mature protein consists of the consensus motif for the LRR superfamily of proteins. These leucine-rich domains organize ALS into a doughnut-shaped structure $(11,12)$. Whereas ALS readily binds to binary complexes of IGFs and IGFBP-3, it does not interact directly with free IGFs and shows only a very low affinity for unliganded IGFBP-3 $(13,14)$. 
So far, eight patients have been described with mutations in the $A L S$ gene (10,15-18). All cases described were characterized by moderate or mild growth failure, undetectable or very low circulating levels of ALS, and markedly reduced plasma concentrations of IGFBP- 3 and IGF-I. In some cases, pubertal delay was noted, and a low bone mineral density (BMD) was found in one case (19).

In this report, we describe three brothers of Kurdish origin with short stature and microcephaly associated with a novel homozygous mutation in the ALS gene. In addition, we have evaluated the clinical and laboratory findings in ten relatives, five of whom were heterozygous for the mutation and five non-carriers.

\section{Methods}

All subjects described in this paper belong to a consanguineous family of Kurdish origin (Fig. 1). After mutation analysis, the subjects were divided into 'patients' (homozygous carriers), heterozygous carriers, and non-carriers. For each homozygous carrier, the medical history as well as the results of previous investigations was retrieved. In 2007, all the subjects were again thoroughly investigated. All the subjects provided written informed consent.

\section{Molecular studies}

Genomic DNA was isolated from whole blood or buffy coats according to the salting out procedure described by Miller et al. (20). All exons of ALS (GenBank accession number AF192554) were PCR amplified and sequenced as described previously (4). The various primer sequences employed are available upon request.

\section{Clinical measurements and auxology}

Physical examination was performed including measurements of height and sitting height with a Harpenden stadiometer and head circumference with a tape measure.

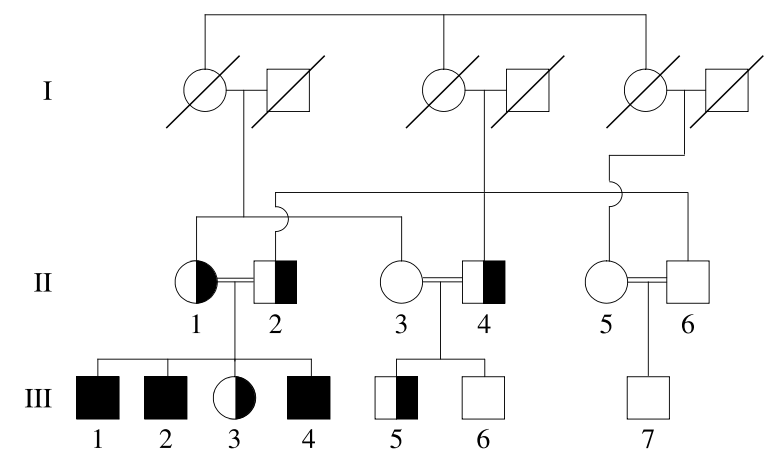

Figure 1 Pedigree of the family. The patients are indicated in black and the heterozygous carriers are indicated in white/black. On the left, the generation number is indicated and the family number is indicated below each individual.
Height was expressed as SDS based on references for Turkish children living in the Netherlands (21). Head circumference and sitting height/height ratio were expressed as SDS for the Dutch population $(22,23)$. Differences between homozygous, heterozygous, and noncarriers were calculated with ANOVA.

\section{Radiological measurements}

BMD was measured by dual energy X-ray absorptiometry using the Hologic Scanner (QDR 4500W) at the lumbar spine, femoral neck, and total body. The volumetric bone mineral apparent density (BMAD) was calculated using the formula: $\operatorname{BMAD}\left(\mathrm{g} / \mathrm{cm}^{3}\right)=$ $\mathrm{BMD} \times(4 / \pi \times$ width of measurement area in lumbar spine) (24). An estimate of the mean width was derived from the scanned area $\left(\mathrm{cm}^{2}\right)$ divided by the height of L2-L4. z-Scores were calculated using the reference data as reported by Fournier et al. (25). Subjects above the age of 20 years were compared with the reference data of the subjects aged 18-20 years. The $z$-score of the subjects below the age of 9 years could not be calculated because there were no appropriate references.

\section{Biochemical measurements}

Plasma levels of IGF-I, IGF-II, IGFBP-1, IGFBP-2, IGFBP-3, IGFBP-4, and IGFBP-6 were determined as described previously (4), and ALS was measured by a commercially available ELISA kit (DSL, Inc., Webster, TX, USA) (26). All measurements were expressed as SDS, except for IGFBP-1 in adults older than 24 years, which was compared with a reference group of six healthy adult controls. The different molecular size classes of endogenous IGF-IGFBP complexes in plasma were determined by neutral gel filtration through a $1.6 \times 60 \mathrm{~cm}$ Hi-Load Superdex-200 column. Prior to column chromatography, each serum sample $(250 \mu \mathrm{l})$ was incubated with $100 \mu \mathrm{l}$ of either $\sim 80000$ c.p.m. ${ }^{125} \mathrm{I}-$ hIGF-I or ${ }^{125}$ I-IGF-II, being dissolved in $50 \mathrm{mM}$ sodium phosphate buffer ( $\mathrm{pH} 7.4$ ), containing $0.2 \%$ BSA, $10 \mathrm{mM}$ EDTA, and $0.05 \%(\mathrm{w} / \mathrm{v})$ Tween-20, for $17 \mathrm{~h}$ at $4{ }^{\circ} \mathrm{C}$. The various molecular size classes of complexes were eluted from the column at a rate of $1.2 \mathrm{ml} / \mathrm{min}$ using $0.05 \mathrm{M}$ $\mathrm{NH}_{4} \mathrm{HCO}_{3}$ buffer (pH 7.4). The ${ }^{125}$ I content of each $1.2 \mathrm{ml}$ fraction was counted in a $\gamma$-counter. The hIGFBP-3 used in several of these experiments was isolated from human plasma according to Martin and Baxter (27). Western blotting on serum samples was performed as described previously (28), using an antibody against human aminoterminal $\mathrm{ALS}_{1-34}$ (DSL, Inc).

\section{Results}

\section{Medical history of the ALS-deficient patients}

Patient III-1 was born as the first of four children of consanguineous parents. In the first three years, he was 
short, frequently ill, had many episodes of diarrhea, and showed poor appetite and night sweating. At the age of 11.6 years, he moved with his family to the Netherlands. At the age of 12 and 14 years, he suffered fractures of the left wrist and arm, after minor trauma, and at radiographs, bone density appeared low. Reported pubertal onset was at about 14 years of age (mean age at Tanner stage 2 in Turkish adolescents living in the Netherlands is 12.2 years) (21). He had a somewhat dysmorphic face with mandibular hypoplasia and a prominent forehead. The growth curve is shown in Fig. 2A.

At the age of 16.1 years, dietary calcium and vitamin D intake appeared low, and serum vitamin D25 was slightly decreased, but serum calcium was in the upper normal range and parathyroid hormone (PTH) was normal. Vitamin D p.o. for 6 months resulted in normalization of D25 levels. A grade I mitral and tricuspid insufficiency was detected at cardiologic investigation. The growth hormone $(\mathrm{GH})$ peak after exercise was high $(63 \mathrm{mU} / \mathrm{l})$, IGF-I was very low $(-6.9$ to -5.0 SDS), and IGFBP-3 extremely low $(-12.0$ SDS). There was a poor response to GH in an IGF-I generation test with two different doses (0.8 and $1.6 \mathrm{mg} / \mathrm{m}^{2}$ per day for 4 days); only on the higher dose IGF-I increased from 16 to $60 \mathrm{ng} / \mathrm{ml}$. IGFBP-3 did not change.

At the age of 17.8 years, his bone age was adult, and he had reached a final height of $149.7 \mathrm{~cm}(-4.2 \mathrm{SDS})$ (Fig. 2A), indicating a fast progression through puberty, which probably led to the poor pubertal height gain $(13.3 \mathrm{~cm})$. At the age of 16,17 , and 19 years, total BMD and $z$-scores were $0.81 \mathrm{~g} / \mathrm{cm}^{2}\left(-3.3\right.$ SDS), $0.89 \mathrm{~g} / \mathrm{cm}^{2}$ $(-3.9 \mathrm{SDS})$, and $0.91 \mathrm{~g} / \mathrm{cm}^{2}(-2.5 \mathrm{SDS})$ respectively, and femoral neck BMD was $0.827(-1.5$ SDS $)$ at 19 years of age.

Patient III-2 moved with his family to the Netherlands at the age of 5 years. At 7 years of age, he was seen by an ophthalmologist because of strabismus. His growth chart is shown in Fig. 2B. Data on reported pubertal onset and progression are inconsistent.

Patient III-4 had a reported birth weight of $2.0 \mathrm{~kg}$ at an unknown gestational age. He remained short during childhood and adolescence (Fig. 2C), but bone maturation was not retarded. During infancy, he experienced poor appetite, frequent episodes of diarrhea, and night sweating. His left leg was $\sim 5 \mathrm{~cm}$ shorter than the right leg, probably due to congenital coxa vara by congenital femoral hypoplasia. After an osteotomy, the difference was reduced to $3 \mathrm{~cm}$. He had a similar dysmorphic face as patient III-1. Puberty onset was reported to have occurred between 12 and 14 years. Total BMD at 6,10 , and 12 years of age was $0.68(-1.3$ SDS $), 0.76\left(-1.2\right.$ SDS), and $0.62 \mathrm{~g} / \mathrm{cm}^{2}$ ( -2.0 SDS) respectively. The GH peak after exercise was high $(118 \mathrm{mU} / \mathrm{l})$, IGF-I was very low $(-4.2$ to -3.8 SDS), and IGFBP-3 extremely low ( $<-17$ SDS). During IGF-I generation tests, employing GH doses 0.8
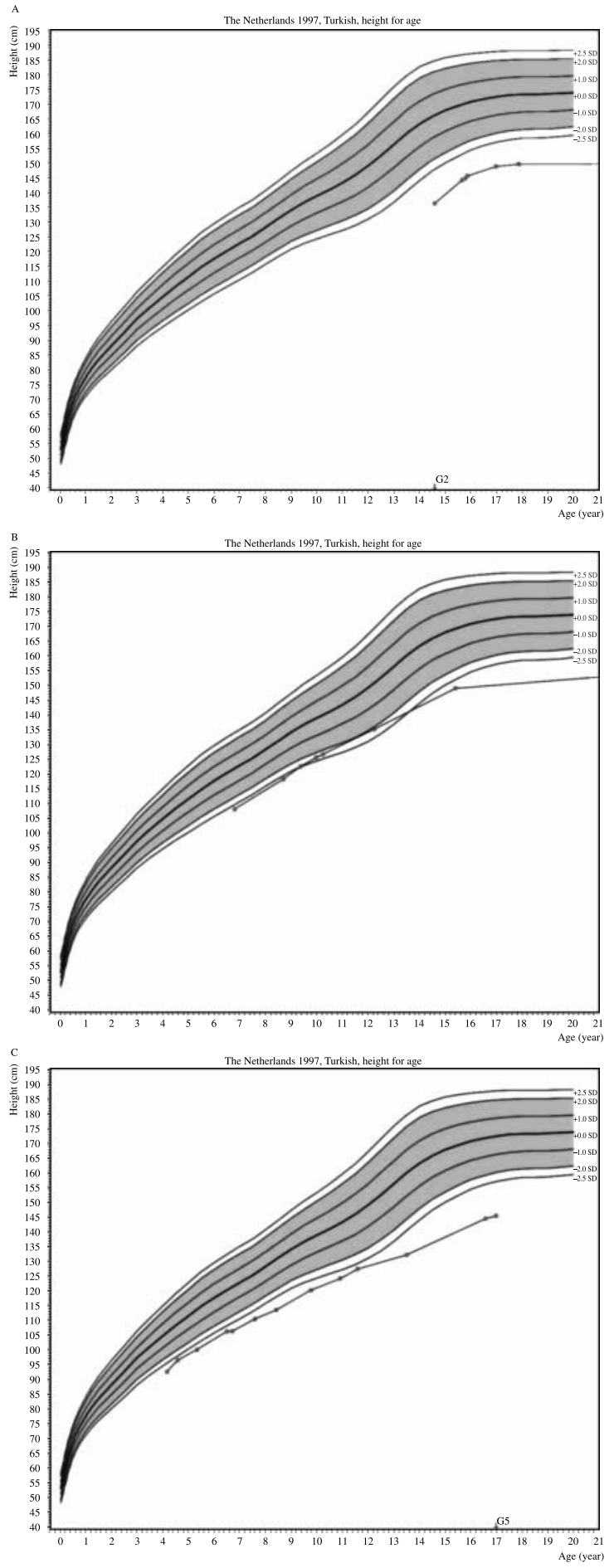

Figure $2(\mathrm{~A}-\mathrm{C})$ Growth curves of patients III-1, III-2, and III-4 (index cases). Target height is $162.0 \mathrm{~cm}(-2.1 \mathrm{SDS})$. Dots represent height measurements, and G2 and G5 indicate Tanner stages 2 and 5.

and $1.6 \mathrm{mg} / \mathrm{m}^{2}$ per day for 4 days, the IGF-I levels increased only marginally, from 38 to $46 \mathrm{ng} / \mathrm{ml}$ and 44 to $52 \mathrm{ng} / \mathrm{ml}$ respectively. DNA analysis for GH and GHR was normal. 


\section{Molecular studies}

Sequence analysis of the ALS gene of patients III-1, III-2, and III-4 revealed a homozygous duplication of a T nucleotide at position 1490 of the coding DNA, resulting in a frameshift and a premature stop codon (c.1490dupT, p.Leu497PhefsX40; further indicated as - / -) (Supplemental Fig. 1, which can be viewed online at http://www. eje-online.org/supplemental/). Five relatives were heterozygous carriers of the mutation $(+/-)$ and the other five non-carriers $(+/+)$ (Fig. 1).

\section{Clinical, radiological, and biochemical features at recall}

Clinical, radiological, and laboratory findings are summarized in Tables 1-3. Mean height and head circumference SDS of heterozygotes were 1 and 0.7 S.D. lower respectively than those of non-carriers, but the differences with non-carriers did not reach statistical significance $(P=0.25$ and 0.13 respectively). The sitting height/ height ratio was in the upper normal range in most cases, without apparent association with the ALS defect. Two homozygous patients exhibited a low BMD and one of them also a low BMAD, but also in four out of nine relatives low values were observed. Tone audiometry did not show a clinically relevant perceptive hearing loss in the patients or their relatives (data not shown).

In the three patients, ALS was not detected by ELISA, which was confirmed by western blotting of patient's sera (Supplemental Fig. 2, which can be viewed online at http://www.eje-online.org/supplemental/). No ALS bands with aberrant molecular weights were detected. Fasting glucose levels were normal $(5.3,4.5$, and $4.6 \mathrm{mmol} / \mathrm{l})$, but insulin was slightly elevated $(12,17$, and $14 \mathrm{mU} / \mathrm{l})$, indicating mild insulin resistance. Plasma levels of IGFBP-3 were extremely low, and of IGF-I, IGF-II, IGFBP-1, and IGFBP-2 markedly reduced. Plasma IGFBP-4 and IGFBP-6, and serum testosterone, folliclestimulating hormone (FSH), luteinizing hormone (LH), and free thyroxine $\left(\mathrm{FT}_{4}\right)$ levels were normal. In heterozygous carriers, plasma ALS and IGFBP-3 were low. In non-carriers, all parameters were normal.

\section{Neutral gel filtration}

While in normal control serum, most IGF-I (90\%) is associated with the $150 \mathrm{kDa}$ complex (Fig. 3A); in the sera of the three ALS-deficient patients there was almost no $150 \mathrm{kDa}$ complex present. The $40-50 \mathrm{kDa}$ fraction (consisting of binary IGF-IGFBP complexes) was markedly elevated and the free ${ }^{125}$ I-IGF-I peak was reduced (Fig. 3B). Addition of purified hIGFBP-3 to these sera did not induce the $150 \mathrm{kDa}$ complex formation, while a slightly increased $150 \mathrm{kDa}$ peak was observed upon addition to normal serum (data not shown). Similar results were obtained with ${ }^{125}$ I-IGF-II (data not shown). In the sera of heterozygous carriers, the amount of the $150 \mathrm{kDa}$ complexes was reduced and that of the 40$50 \mathrm{kDa}$ complexes markedly increased (Fig. 3C). Column profiles of sera of the non-carriers were normal.

\section{Discussion}

We report three brothers of Kurdish origin, born from a consanguineous family, with a novel homozygous frameshift mutation in the $A L S$ gene, presenting with short stature and microcephaly. In two cases a low BMD was observed, in one of them twice resulting in a fracture; but further studies of BMD in their relatives

Table 1 Clinical features and biochemical characteristics of the homozygous carriers.

\begin{tabular}{|c|c|c|c|c|}
\hline & III-1 & III-2 & III-4 & Mean \\
\hline IGFALS gene & $-1-$ & $-1-$ & $-1-$ & \\
\hline Gender & M & $\mathrm{M}$ & M & \\
\hline Age (year) & 27.2 & 21.5 & 17.0 & 21.9 \\
\hline Height $(\mathrm{cm})(\mathrm{SDS})$ & $149.7(-4.2)$ & $153.2(-3.6)$ & $145.5(-4.4)$ & $149.5(-4.1)$ \\
\hline Head circumference $(\mathrm{cm})(\mathrm{SDS})$ & $52.5(-3.0)$ & $53.3(-2.6)$ & $51.2(-3.2)$ & $52.3(-2.9)$ \\
\hline BMI $\left(\mathrm{kg} / \mathrm{m}^{2}\right)$ & 21.2 & 23.4 & 21.6 & 22.1 \\
\hline Sitting height: Height (SDS) & $0.54(2.2)$ & $0.54(2.0)$ & $0.53(1.1)$ & $0.54(1.8)$ \\
\hline Total BMD $\left(\mathrm{g} / \mathrm{cm}^{2}\right)$ (z-score) & 0.865 & 1.058 & $0.793(-3.3)$ & 0.905 \\
\hline BMD femoral neck ( $z$-score) & $0.591(-2.4)$ & $0.943(0.1)$ & $0.640(-2.4)$ & $0.725(-1.6)$ \\
\hline BMD L1-L4 (z-score) & $0.625(-4.2)$ & $0.902(-1.7)$ & $0.590(-3.1)$ & $0.706(-3.0)$ \\
\hline BMAD L2-L4 (z-score) & $0.209(-2.8)$ & $0.284(-0.2)$ & $0.230(-1.7)$ & $0.241(-1.6)$ \\
\hline IGF-I (ng/ml) (SDS) & $<12(<-7.2)$ & $13(-7.4)$ & $29(-5.6)$ & $18(-6.7)$ \\
\hline IGF-II (ng/ml) (SDS) & $66(-6.6)$ & $55(-6.8)$ & $49(-6.7)$ & $56.7(-6.7)$ \\
\hline IGFBP-1 (ng/ml) (SDS) ${ }^{a}$ & 27 & $12(-1.5)$ & $9(-2.2)$ & 16 \\
\hline IGFBP-2 (ng/ml) (SDS) & $67(-2.5)$ & $95(-1.8)$ & $69(-3.0)$ & $77(-2.4)$ \\
\hline IGFBP-3 (mg/l) (SDS) & $0.09(-18.2)$ & $0.09(-18.5)$ & $0.10(-17.6)$ & $0.10(-18.1)$ \\
\hline IGFBP-4 (ng/ml) (SDS) & $172(-0.1)$ & $136(-0.7)$ & $157(-0.3)$ & $155(-0.4)$ \\
\hline IGFBP-6 (ng/ml) (SDS) & $180(0.4)$ & $138(-0.3)$ & $148(0.2)$ & $155.3(0.1)$ \\
\hline ALS (mg/l) (SDS) & $<0.07(<-7.1)$ & $<0.07(<-5.7)$ & $<0.07(<-4.5)$ & $<0.07(<-4.5)$ \\
\hline
\end{tabular}

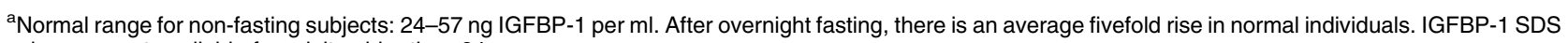
values are not available for adults older than 24 years. 
Table 2 Clinical features and biochemical characteristics of the heterozygous carriers.

\begin{tabular}{|c|c|c|c|c|c|c|}
\hline & II-1 & II-2 & II-4 & III-3 & III-5 & Mean \\
\hline IGFALS gene & $+/-$ & $+1-$ & $+1-$ & $+1-$ & $+1-$ & \\
\hline Gender & $\mathrm{F}$ & $M$ & $\mathrm{M}$ & $\mathrm{F}$ & $\mathrm{M}$ & \\
\hline Age (year) & 46.1 & 52.2 & 41.6 & 20.1 & 7.4 & 33.5 \\
\hline Height (cm) (SDS) & $141.7(-3.4)$ & $155.5(-3.2)$ & $154.8(-3.3)$ & $149.8(-2.0)$ & $126.3(0.3)$ & $145.6(-2.3)$ \\
\hline $\begin{array}{l}\text { Head circumference }(\mathrm{cm}) \\
\text { (SDS) }\end{array}$ & $53.8(-0.9)$ & $54.0(-2.2)$ & $55.0(-1.6)$ & $52.5(-1.7)$ & $51.6(-0.4)$ & $53.4(-1.4)$ \\
\hline BMI $\left(\mathrm{kg} / \mathrm{m}^{2}\right)$ & 27.2 & 24.3 & 27.0 & 24.4 & 14.7 & 23.5 \\
\hline Sitting height: height (SDS) & $0.53(0.4)$ & $0.54(2.1)$ & $0.53(1.2)$ & $0.53(0.6)$ & $0.53(-0.4)$ & $0.53(0.8)$ \\
\hline Total BMD ( $\left.\mathrm{g} / \mathrm{cm}^{2}\right)$ ( $z$-score) & $0.974(-0.9)$ & 0.869 & 0.986 & $0.911(-2.2)$ & $0.751(0.4)$ & $0.898(-0.9)$ \\
\hline BMD femoral neck ( $z$-score) & $0.721(-0.7)$ & $0.648(-1.3)$ & $0.855(0.0)$ & $0.811(-0.3)$ & $0.732(1.4)$ & $0.753(-0.2)$ \\
\hline BMD L1-L4 (z-score) & $0.805(-1.7)$ & $0.618(-3.9)$ & $0.692(-3.5)$ & $0.865(-1.4)$ & $0.577(0.7)$ & $0.711(-2.0)$ \\
\hline BMAD L2-L4 (z-score) & $0.307(-0.4)$ & $0.164(-4.4)$ & $0.184(-3.7)$ & $0.308(-0.4)$ & 0.169 & $0.226(-2.2)$ \\
\hline IGF-I (ng/ml) (SDS) & $99(-1.1)$ & $73(-1.5)$ & $86(-1.6)$ & $141(-1.8)$ & $73(-1.4)$ & $94(-1.5)$ \\
\hline IGF-II (ng/ml) (SDS) & $352(-1.0)$ & $305(-1.8)$ & $305(-1.7)$ & $308(-1.5)$ & $296(-1.1)$ & $313.2(-1.4)$ \\
\hline IGFBP-1 (ng/ml) SDS) ${ }^{a}$ & 11 & 31 & 5 & $19(-1.7)$ & $164(0.1)$ & 46 \\
\hline IGFBP-2 (ng/ml) (SDS) & $184(0.1)$ & $196(0.3)$ & $255(0.9)$ & $278(1.5)$ & $360(1.1)$ & $255(0.8)$ \\
\hline IGFBP-3 (mg/l) (SDS) & $1.54(-1.2)$ & $0.93(-2.9)$ & $0.94(-3.3)$ & $1.19(-3.2)$ & $1.05(-2.9)$ & $1.13(-2.7)$ \\
\hline IGFBP-4 (ng/ml) (SDS) & $196(0.3)$ & $117(-1.1)$ & $139(-0.7)$ & $139(-0.8)$ & $113(-1.2)$ & $141(-0.7)$ \\
\hline IGFBP-6 (nq/ml) (SDS) & $185(0.8)$ & $176(-0.3)$ & $159(-0.3)$ & $147(0.1)$ & $112(0.3)$ & $156(0.1)$ \\
\hline ALS (mg/l) (SDS) & $9.9(-2.6)$ & $10.5(-1.9)$ & $6.0(-3.6)$ & $9.0(-3.0)$ & $6.9(-2.0)$ & $8.5(-2.6)$ \\
\hline
\end{tabular}

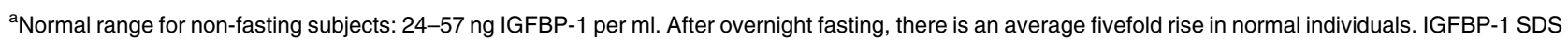
values are not available for adults older than 24 years.

suggest that other genetic factors may be involved. Biochemically, serum ALS was undetectable; IGFBP-3 extremely low; IGFs, IGFBP-2, and IGFBP-1 decreased; and the ternary $150 \mathrm{kDa}$ complex was virtually absent. Most of the circulating IGFs were either sequestered by IGFBPs forming binary complexes or remained unbound. The western blotting experiments indicate that there is no truncated form of ALS present. Even if this were the case, a truncated ALS would not be able to form the stable 3D doughnut-shaped structure, which is essential for its function.
The growth pattern of all previously reported cases of ALS deficiency $(10,15,16,18)$ is characterized by moderate or mild short stature during childhood and adolescence and a normal or slightly decreased adult stature. Our ALS-deficient patients are much shorter in comparison with the reference population, but this may be due to other genetic factors in this highly consanguineous family. The difference between their mean (near) adult height SDS $(-4.1$ SDS) and that of the five heterozygous carriers ( -2.3 SDS) is 1.7 s.D., comparable with earlier reports. Data on head circumference have not

Table 3 Clinical features and biochemical characteristics of the non-carriers.

\begin{tabular}{|c|c|c|c|c|c|c|}
\hline & II-3 & II-5 & II-6 & III-6 & III-7 & Mean \\
\hline $\begin{array}{l}\text { IGFALS gene } \\
\text { Gender }\end{array}$ & $\begin{array}{l}+/+ \\
\mathrm{F}\end{array}$ & $\begin{array}{l}+/+ \\
\mathrm{F}\end{array}$ & $\stackrel{+/+}{M}$ & $\begin{array}{l}+/+ \\
M\end{array}$ & $\stackrel{+/+}{M}$ & \\
\hline Age (year) & 34.3 & 32.7 & 37.6 & 5.6 & 5.6 & 23.2 \\
\hline Height $(\mathrm{cm})(\mathrm{SDS})$ & $151.3(-1.7)$ & $160.6(0.0)$ & $156.6(-3.0)$ & $114.5(-0.1)$ & $107.0(-1.8)$ & $138.0(-1.3)$ \\
\hline Head circumference $(\mathrm{cm})(\mathrm{SDS})$ & $53.0(-1.4)$ & $54.0(-0.8)$ & $56.0(-1.0)$ & $52.0(0.2)$ & $50.5(-0.7)$ & $53.1(-0.7)$ \\
\hline BMI $\left(\mathrm{kg} / \mathrm{m}^{2}\right)$ & 24.4 & 25.4 & 27.1 & 14.6 & 13.8 & 21.1 \\
\hline Sitting height: height (SDS) & $0.53(0.4)$ & $0.55(1.5)$ & $0.55(2.5)$ & $0.54(-0.2)$ & $0.54(-0.3)$ & $0.54(0.8)$ \\
\hline Total BMD $\left(\mathrm{g} / \mathrm{cm}^{2}\right)$ (z-score) & $1.037(-0.5)$ & $0.905(-2.0)$ & 1.013 & $0.668(-0.1)$ & - & $0.906(-0.9)$ \\
\hline BMD femoral neck ( $z$-score) & $0.700(-1.2)$ & $0.683(-1.4)$ & $0.787(-0.6)$ & $0.659(1.6)$ & - & $0.707(-0.4)$ \\
\hline BMD L1-L4 (z-score) & $0.903(-1.3)$ & $0.778(-2.4)$ & $0.754(-3.0)$ & $0.434(-1.3)$ & - & $0.717(-2.0)$ \\
\hline BMAD L2-L4 (z-score) & $0.277(-1.3)$ & $0.239(-2.4)$ & $0.202(-3.1)$ & 0.141 & - & $0.215(-2.3)$ \\
\hline IGF-I (ng/ml) (SDS) & $199(0.8)$ & $164(0.0)$ & $81(-1.9)$ & $144(1.1)$ & $77(-0.5)$ & $133(-0.1)$ \\
\hline IGF-II (ng/ml) (SDS) & $436(0.1)$ & $543(1.2)$ & $441(0.1)$ & $546(1.5)$ & $302(-0.9)$ & $454(0.4)$ \\
\hline IGFBP-1 (ng/ml) (SDS) ${ }^{a}$ & $<5$ & 20 & 78 & $125(-1.0)$ & $81(-2.0)$ & 62 \\
\hline IGFBP-2 (ng/ml) (SDS) & $237(0.7)$ & $156(-0.2)$ & $336(1.5)$ & $242(-0.5)$ & $426(1.5)$ & $279(0.6)$ \\
\hline IGFBP-3 (mg/l) (SDS) & $1.94(-0.6)$ & $2.0(-0.6)$ & $1.6(-1.2)$ & $2.52(0.9)$ & $1.66(-0.7)$ & $1.9(-0.4)$ \\
\hline IGFBP-4 (ng/ml) (SDS) & $79(-2.0)$ & $91(-1.8)$ & $133(-0.8)$ & $126(-0.9)$ & $105(-1.3)$ & $107(-1.4)$ \\
\hline IGFBP-6 (ng/ml) (SDS) & $125(-0.3)$ & $159(0.5)$ & $187(0.4)$ & $130(1.2)$ & $75.2(-0.7)$ & $135.2(0.2)$ \\
\hline ALS (mg/l) (SDS) & $14.5(-1.5)$ & - & - & $16.1(1.7)$ & - & $15.3(0.1)$ \\
\hline
\end{tabular}

To convert IGF-I to nmol/I, multiply by 0.131 ; IGF-II to nmol//, multiply by 0.134 ; ALS to $\mathrm{nmol} / \mathrm{l}$, multiply by 15.8 ; IGFBP-1 to $\mathrm{nmol} / \mathrm{I}$, multiply by 0.033 ; IGFBP-2 to $\mathrm{nmol} / \mathrm{l}$, multiply by 0.032 ; IGFBP-3 to nmol//, multiply by 33.3 ; IGFBP-4 to nmol//, multiply by 0.038 ; and IGFBP-6 to nmol/l, multiply by 0.034 .

aNormal range for non-fasting subjects: $24-57 \mathrm{ng}$ IGFBP-1 per ml. After overnight $(\mathrm{o} / \mathrm{h})$ fasting, there is an average fivefold rise in normal individuals. IGFBP-1 SDS values are not available for adults older than 24 years. 

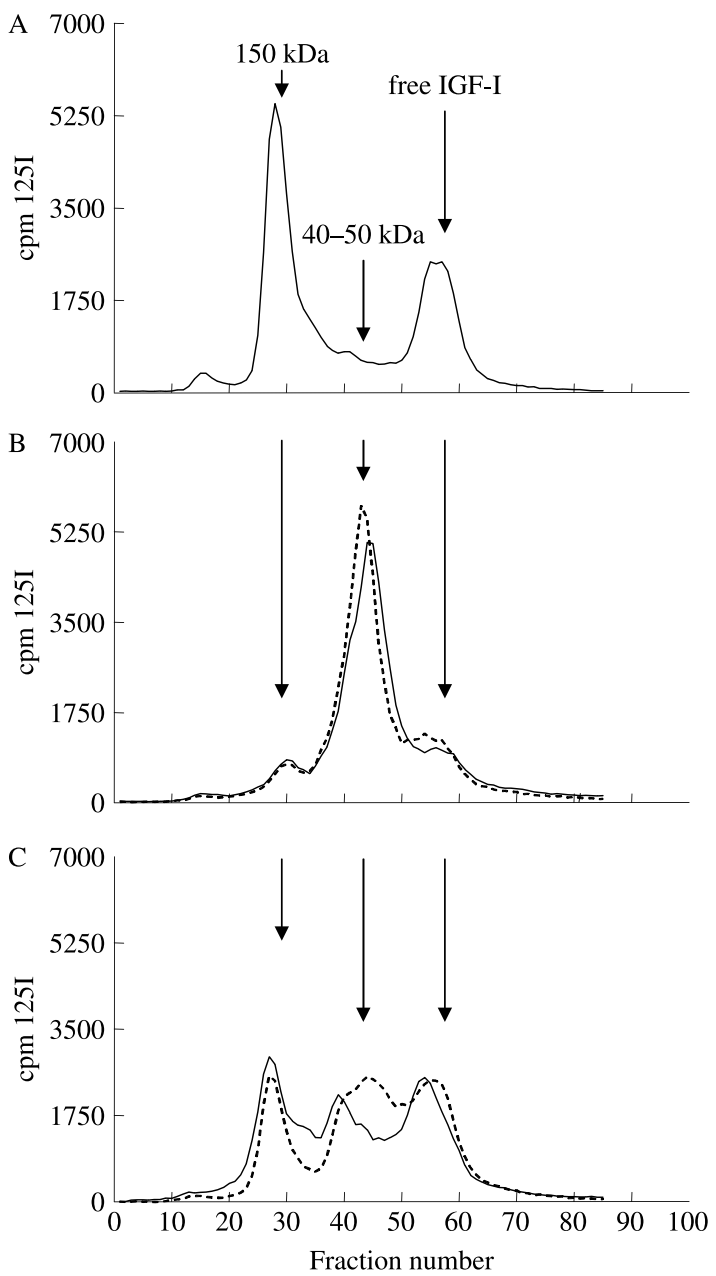

Figure 3 S200 gel filtration column chromatography. (A) Representative column profile for normal adult serum. (B) Serum of patient III-1 (solid line) and patient III-2 (dotted line), both exhibiting a homozygous mutation in the ALS gene. (C) Serum of the father II-2 (solid line) and uncle (II-4) (dotted line) of the index cases, both being heterozygous for the mutation.

been presented in earlier reports; thus it remains to be established whether microcephaly represents a clinical feature of homozygous ALS deficiency.

The growth pattern in humans with ALS deficiency is comparable with the mild growth failure observed in $A L S$ gene knock-out (ALS-KO) mice, and is in contrast with the severe growth failure as observed in patients with a total IGF-I deficiency (2). This is in line with the hypothesis that the contribution of locally produced IGF-I to longitudinal growth is more important than that of IGF-I derived from the circulation $(10,17)$. As speculated previously, local production of IGF-I may be even higher than normal due to increased $\mathrm{GH}$ secretion, and might thereby compensate, at least in part, for any deficiency of circulating IGF-I (10). Another possible explanation of the near-normal growth, in spite of reduced levels of circulating IGF-I, may include an increase in the IGF-I flux toward the peripheral tissue compartments at the expense of the circulating IGF-I pool that cannot be maintained at normal levels without ALS $(17,29)$. It is uncertain whether ALS deficiency affects fetal growth.

At present, it is uncertain whether an ALS defect is associated with pubertal delay. Three patients described previously seem to have experienced late onset of puberty $(17,18)$, but in the other cases puberty was normal. In our index patient III-1, pubertal onset was late, in III-2 unknown, and in III-4 normal. The low BMD in two of our patients and in the first published case (19), in combination with the low BMD in ALS-KO mice (30-32) and previous studies showing that circulating IGF-I levels are related to sufficient bone growth and acquisition of peak bone mass $(33,34)$, suggested that ALS deficiency might be associated with a low BMD. However, further observations in the patients' relatives did not support this.

Biochemically, in all cases reported so far, undetectable or very low levels of circulating ALS, extremely low IGFBP-3, and low IGF-I and IGF-II have been reported. The lack of the $150 \mathrm{kDa}$ complex formation is expected to shorten the half-life of IGF-I in the circulation (31), and possibly also that of IGFBP-3 (10). The low IGFBP-1 and IGFBP-2 plasma levels observed in two earlier papers $(16,18)$ and in our three patients suggest that this is part of the syndrome. A consequence of the low plasma IGFBP-1 (an inhibitor of IGF-I effects) may be that growth is less compromised than would be expected from the low circulating IGF-I levels alone.

In the cases tested, we found an increased $\mathrm{GH}$ response to provocative stimuli, confirming earlier observations $(10,16,18)$. The increased GH secretion can be explained by the reduction in free IGF-I as observed in previous studies $(10,35,36)$, but is in contrast to the normal free IGF-I and GH levels in ALSKO mice $(19,31)$. An IGF generation test was performed in three previous cases $(10,16,18)$, and showed virtually no response of IGF-I, similar to the two cases tested. Our patients had a mild insulin resistance, confirming earlier reports $(16,18)$.

Heterozygosity for an ALS defect may have some effect on stature and head circumference compared with noncarriers, but these differences did not reach statistical significance. Within the heterozygous and wild-type individuals, height and head circumference varied considerably, which may be due to other genes that negatively affect growth in this highly consanguineous family. As in most previous reports, parents of affected patients were relatively short $(10,18)$; a meta-analysis of all cases may shed more light on this issue. Biochemically, carriers had low plasma ALS and IGFBP-3, and IGF-I in the low normal range, as reported previously (10).

In conclusion, these three cases with a novel frameshift mutation of $A L S$ resulting in undetectable circulating ALS levels show that besides short stature 
and possible delayed onset of puberty, microcephaly may also be part of the syndrome. Biochemically, the absence of circulating ALS leads to extremely low levels of IGFBP-3, very low levels of IGF-I and IGF-II, low plasma IGFBP-1 and IGFBP-2, and mild insulin resistance. Heterozygosity for an ALS defect may have a small effect on height and head circumference.

\section{References}

1 Walenkamp MJ \& Wit JM. Genetic disorders in the growth hormone - insulin-like growth factor-I axis. Hormone Research $200666221-230$.

2 Walenkamp MJ \& Wit JM. Genetic disorders in the GH IGF-I axis in mouse and man. European Journal of Endocrinology $2007 \mathbf{1 5 7}$ S15-S26.

3 Woods KA, Camacho-Hubner C, Savage MO \& Clark AJ. Intrauterine growth retardation and postnatal growth failure associated with deletion of the insulin-like growth factor I gene. New England Journal of Medicine 1996335 1363-1367.

4 Walenkamp MJ, Karperien M, Pereira AM, Hilhorst-Hofstee Y, van Doorn J, Chen JW, Mohan S, Denley A, Forbes B, van Duyvenvoorde HA, van Thiel SW, Sluimers CA, Bax JJ, de Laat JA, Breuning MB, Romijn JA \& Wit JM. Homozygous and heterozygous expression of a novel insulin-like growth factor-I mutation. Journal of Clinical Endocrinology and Metabolism 2005902855 2864.

5 Abuzzahab MJ, Schneider A, Goddard A, Grigorescu F, Lautier C, Keller E, Kiess W, Klammt J, Kratzsch J, Osgood D, Pfaffle R, Raile K, Seidel B, Smith RJ \& Chernausek SD. IGF-I receptor mutations resulting in intrauterine and postnatal growth retardation. New England Journal of Medicine 2003349 2211-2222.

6 Kawashima Y, Kanzaki S, Yang F, Kinoshita T, Hanaki K, Nagaishi J, Ohtsuka Y, Hisatome I, Ninomoya H, Nanba E, Fukushima T \& Takahashi S. Mutation at cleavage site of insulinlike growth factor receptor in a short-stature child born with intrauterine growth retardation. Journal of Clinical Endocrinology and Metabolism 200590 4679-4687.

7 Walenkamp MJ, van der Kamp HJ, Pereira AM, Kant SG, van Duyvenvoorde HA, Kruithof MF, Breuning MH, Romijn JA, Karperien M \& Wit JM. A variable degree of intrauterine and postnatal growth retardation in a family with a missense mutation in the insulin-like growth factor I receptor. Journal of Clinical Endocrinology and Metabolism 200691 3062-3070.

8 Inagaki K, Tiulpakov A, Rubtsov P, Sverdlova P, Peterkova V, Yakar S, Terekhov S \& LeRoith D. A familial insulin-like growth factor-I receptor mutant leads to short stature: clinical and biochemical characterization. Journal of Clinical Endocrinology and Metabolism 200792 1542-1548.

9 Boisclair YR, Rhoads RP, Ueki I, Wang J \& Ooi GT. The acid-labile subunit (ALS) of the $150 \mathrm{kDa}$ IGF-binding protein complex: an important but forgotten component of the circulating IGF system. Journal of Endocrinology 2001170 63-70.

10 Hwa V, Haeusler G, Pratt KL, Little BM, Frisch H, Koller D \& Rosenfeld RG. Total absence of functional acid labile subunit, resulting in severe insulin-like growth factor deficiency and moderate growth failure. Journal of Clinical Endocrinology and Metabolism 200691 1826-1831.

11 Janosi JB, Ramsland PA, Mott MR, Firth SM, Baxter RC \& Delhanty PJ. The acid-labile subunit of the serum insulin-like growth factor-binding protein complexes. Structural determination by molecular modeling and electron microscopy. Journal of Biological Chemistry 1999274 23328-23332.

12 Janosi JB, Firth SM, Bond JJ, Baxter RC \& Delhanty PJ. N-Linked glycosylation and sialylation of the acid-labile subunit. Role in complex formation with insulin-like growth factor (IGF)-binding protein-3 and the IGFs. Journal of Biological Chemistry $1999 \mathbf{2 7 4}$ 5292-5298.

13 Baxter RC \& Martin JL. Structure of the Mr 140000 growth hormone-dependent insulin-like growth factor binding protein complex: determination by reconstitution and affinity-labeling. PNAS 198986 6898-6902.

14 Twigg SM \& Baxter RC. Insulin-like growth factor (IGF)-binding protein 5 forms an alternative ternary complex with IGFs and the acid-labile subunit. Journal of Biological Chemistry 1998273 6074-6079.

15 Campos-Barros A, Heath KE, Diaz-González F, Barrios V, Martos GA, Pozo J, Caimari M, Gracia R \& Argente J. IGFALS mutations define a new form of impaired postnatal growth associated to low circulating IGF-I, IGFBP-3, and acid-labile subunit (ALS) levels. Hormone Research $2007 \mathbf{6 8} 33$.

16 Domene HM, Bengolea SV, Martinez AS, Ropelato MG, Pennisi P, Scaglia P, Heinrich JJ \& Jasper HG. Deficiency of the circulating insulin-like growth factor system associated with inactivation of the acid-labile subunit gene. New England Journal of Medicine 2004 $350570-577$.

17 Domene HM, Martinez AS, Frystyk J, Bengolea SV, Ropelato MG, Scaglia PA, Chen JW, Heuck C, Wolthers OD, Heinrich JJ \& Jasper HG. Normal growth spurt and final height despite low levels of all forms of circulating insulin-like growth factor-I in a patient with acid-labile subunit deficiency. Hormone Research 200767 243-249.

18 Domene HM, Scaglia PA, Lteif A, Mahmud FH, Kirmani S, Frystyk J, Bedecarras P, Gutierrez M \& Jasper HG. Phenotypic effects of null and haploinsufficiency of acid-labile subunit in a family with two novel IGFALS gene mutations. Journal of Clinical Endocrinology and Metabolism 200792 4444-4450.

19 Domene HM, Bengolea SV, Jasper HG \& Boisclair YR. Acid-labile subunit deficiency: phenotypic similarities and differences between human and mouse. Journal of Endocrinological Investigation 2005 28 43-46.

20 Miller SA, Dykes DD \& Polesky HF. A simple salting out procedure for extracting DNA from human nucleated cells. Nucleic Acids Research 1988161215.

21 Fredriks AM, van Buuren S, Jeurissen SE, Dekker FW, VerlooveVanhorick SP \& Wit JM. Height, weight, body mass index and pubertal development reference values for children of Turkish origin in the Netherlands. European Journal of Pediatrics 2003162 788-793.

22 Fredriks AM, van Buuren S, Burgmeijer RJ, Meulmeester JF, Beuker RJ, Brugman E, Roede MJ, Verloove-Vanhorick SP \& Wit JM. Continuing positive secular growth change in The Netherlands 1955-1997. Pediatric Research 200047 316-323.

23 Fredriks AM, van Buuren S, van Heel WJ, Dijkman-Neerincx RH, Verloove-Vanhorick SP \& Wit JM. Nationwide age references for sitting height, leg length, and sitting height/height ratio, and their diagnostic value for disproportionate growth disorders. Archives of Disease in Childhood 200590 807-812.

24 Kroger H, Kotaniemi A, Vainio P \& Alhava E. Bone densitometry of the spine and femur in children by dual-energy x-ray absorptiometry. Bone and Mineral 199217 75-85.

25 Fournier PE, Rizzoli R, Slosman DO, Theintz G \& Bonjour JP. Asynchrony between the rates of standing height gain and bone mass accumulation during puberty. Osteoporosis International $19977525-532$.

26 Yu H, Mistry J, Nicar MJ, Khosravi MJ, Diamandis A, van Doorn J \& Juul A. Insulin-like growth factors (IGF-I, free IGF-I and IGF-II) and insulin-like growth factor binding proteins (IGFBP-2, IGFBP-3, IGFBP-6, and ALS) in blood circulation. Journal of Clinical Laboratory Analysis 199913 166-172.

27 Martin JL \& Baxter RC. Insulin-like growth factor-binding protein from human plasma. Purification and characterization. Journal of Biological Chemistry $19862618754-8760$.

28 Ouwens DM, van der Zon GC, Pronk GJ, Bos JL, Moller W, Cheatham B, Kahn CR \& Maassen JA. A mutant insulin receptor induces formation of a Shc-growth factor receptor bound protein 2 
(Grb2) complex and p21ras-GTP without detectable interaction of insulin receptor substrate 1 (IRS1) with Grb2. Evidence for IRS1independent p21ras-GTP formation. Journal of Biological Chemistry $199426933116-33122$.

29 Payet LD, Firth SM \& Baxter RC. The role of the acid-labile subunit in regulating insulin-like growth factor transport across human umbilical vein endothelial cell monolayers. Journal of Clinical Endocrinology and Metabolism $2004892382-2389$.

30 Beamer WG, Donahue LR, Rosen CJ \& Baylink DJ. Genetic variability in adult bone density among inbred strains of mice. Bone 199618 397-403.

31 Yakar S, Rosen CJ, Beamer WG, Ackert-Bicknell CL, Wu Y, Liu JL, Ooi GT, Setser J, Frystyk J, Boisclair YR \& LeRoith D. Circulating levels of IGF-1 directly regulate bone growth and density. Journal of Clinical Investigation $2002110771-781$.

32 Hildebrand T, Laib A, Muller R, Dequeker J \& Ruegsegger P. Direct three-dimensional morphometric analysis of human cancellous bone: microstructural data from spine, femur, iliac crest, and calcaneus. Journal of Bone and Mineral Research 199914 1167-1174.

33 Langlois JA, Rosen CJ, Visser M, Hannan MT, Harris T, Wilson PW \& Kiel DP. Association between insulin-like growth factor I and bone mineral density in older women and men: the Framingham Heart Study. Journal of Clinical Endocrinology and Metabolism 1998 83 4257-4262.

34 Rosen CJ, Dimai HP, Vereault D, Donahue LR, Beamer WG, Farley J, Linkhart S, Linkhart T, Mohan S \& Baylink DJ. Circulating and skeletal insulin-like growth factor-I (IGF-I) concentrations in two inbred strains of mice with different bone mineral densities. Bone $199721217-223$.

35 Daughaday WH. Circulating IGF-I deficiency and inactivation of the acid-labile subunit gene. New England Journal of Medicine 2004 3501906.

36 Chapman IM, Hartman ML, Pieper KS, Skiles EH, Pezzoli SS, Hintz RL \& Thorner MO. Recovery of growth hormone release from suppression by exogenous insulin-like growth factor I (IGF-I): evidence for a suppressive action of free rather than bound IGF-I. Journal of Clinical Endocrinology and Metabolism $1998 \mathbf{8 3} 2836-2842$.

Received 18 April 2008

Accepted 5 May 2008 